ЗАБЕЗПЕЧЕННЯ ГНУЧКОСТІ ПРИЙНЯТТЯ

УПРАВЛІНСЬКИХ РІШЕНЬ ТА ЦИФРОВІЗАЦІї УПРАВЛІННЯ НА ІННОВАЦІЙНИХ ПІДПРИЄМСТВАХ І СТАРТАПАХ

\title{
ENSURING FLEXIBILITY IN MANAGEMENT DECISION-MAKING AND DIGITALIZATION OF MANAGEMENT AT INNOVATIVE ENTERPRISES AND STARTUPS
}

Удк 338:316

DOI: https://doi.org/10.32843/infrastruct49-16

\section{Богоявленська Ю.В.}

к.е.н., доцент

Державний університет

«Житомирська політехніка»

Свірко С.В.

д.е.н., професор

Державний університет

«Житомирська політехніка»

Бережницький д.Ю.

магістрант

Державний університет

«Житомирська політехніка»

\section{Bogoyavlenska Yuliya}

Zhytomyr Polytechnic State University Svirko Svitlana

Zhytomyr Polytechnic State University

Berezhnytskyi Dmytro

Zhytomyr Polytechnic State University
У статті розкрито особливості цифрровізації управління, досліджено управлінські рішення та їх прийняття з позиції гнучкості, проведено аналіз сучасного досвіду. На основі проведеного аналізу визначено напрями удосконалення управління на інноваційних підприємствах і стартапах. Запропоновано застосовувати методологічний підхід до прийняття управлінських рішень з позиції гнучкості, що передбачає можливість коригування такого рішення в разі суттєвої зміни певних умов їі функкціонування. Запропоновано актуальні інструменти для забезпечення гнучкості прийняття управлінських рішень у сучасних умовах. Встановлено, що на підприємствах інноваційного типу відсоток цифровізаціі управління становить близько $30 \%$, а в стартапах - 50\%, що змінюватиметься на користь зростання й надалі внаслідок зміни форм і видів зайнятості, форматів роботи і підходів до управління та реалізації таких фуункцій, як планування, організація, координація, контроль завдяки розвитку циорровізації; мотивація ж вимагатиме збереження офрлайн-фрормату.

Ключові слова: чифрровізація управління, управлінські рішення, гнучкість прийняття управлінських рішень, інноваційні підприємства, стартапи.
В статье раскрыты особенности цисрровизации управления, исследованы управленческие решения и их принятие с позиции гибкости, проанализирован существующий опыт. На основе анализа определены направления совершенствования управления на инновационных предприятиях u стартапах. Предлагается применять методологический подход к принятию управленческих решений с позиции гибкости, которая предусматривает возможность корректировки такого решения в случае существенного изменения определенных условий его фуункционирования. Предлагаются актуальные инструменты для обеспечения гибкости принятия управленческих решений в современных условиях. Установлено, что на предприятиях инновационного типа доля цифровизации управления составляет около $30 \%$, а в стартапах $50 \%$, и в дальнейшем она возрастет за счет изменений фрорм и видов занятости форматов работы и подходов к управлению и реализации фуункций планирования, организации, координации, контроля благодаря развитию цисровизации; мотивация потребует сохранения офрлайн-формата.

Ключевые слова: чифровизачия управления, управленческие решения, гибкость принятия управленческих решений, инновационные предприятия, стартапы.

The article considers the main peculiarities of digitalization of management, investigates management decisions and their adoption from a position of flexibility, analyzes modern experience. Attention paid on innovative companies and their contribution to the development of the world economy-2020, which presented through the point of view of the top 5 startups of Ukrainian origin, which continue to attract investments and investors. Despite of pandemic conditions Ukrainian startups scaling up to the level of unicorn, and it is possible under the technical and managerial support to quick response on the requests of the markets, whatever they are global or local. On the basis of the analysis, the directions of improvement of management at innovative enterprises and startups are determined. It is proposed to apply a methodological approach to the adoption of management decisions in terms of flexibility, which provides for the possibility of adjusting such a decision in case of a significant change in certain conditions of its functioning. It is mentioned that in collective and strong teams flexibility have to be extended to the issue of distribution of roles in startup teams, statuses and organizational structure, distribution of works at innovative enterprises; and, the advantage of innovative enterprises is in maximum involvement of teams in the development and implementation of ideas and solutions, in the possibility of creating conditions for understanding the personal responsibility of everyone for the result. Actual tools are offered to ensure flexibility of management decision-making in modern conditions. It was established that the percentage of digitalization of management on enterprises of innovative type is about $30 \%$, and in startups $50 \%$, which will change in favor of growth in the future due to changes in forms and types of employment, formats of work and approaches to the management and implementation of such functions as planning, organization, coordination, control through the development of digitalization; motivation will require the preservation of the offline format.

Key words: management of digitalization, management decisions, flexibility of management solutions making, innovative enterprises, startups.

Постановка проблеми. У сучасних умовах діджиталізації прийняття управлінських рішень вимагає нових підходів, що зумовлено пришвидшенням всіх процесів, а особливо управлінських. Системи управління підприємств уже не можна розглядати диференційовано від функціонування екосистеми інноваційного підприємництва, стартапів, венчурних інвесторів, університетських платорорм, колаборації інститутів та інституцій.

Процес цифрровізації управління має відповідати реальним умовам здійснення діяльності суб'єктами господарювання та забезпечувати зростання продуктивності праці й показників ефективності. Підвищення вимог до прийняття якісних управлінських рішень каталізується появою кластеру креативних індустрій і його динамічним розвитком, а також появою стартапів, зароджених в українській економіці як реакція на необхідність «вгамовування болі» клієнтів та задоволення як їхніх потреб, так і потреб економіки. Водночас есрективне управління вимагає розкриття талантів, розвитку навичок працівників та їхніх компетенцій, розроблення ефрективних мотиваційних 
систем, що найбільш продуктивно можливо реалізовувати в умовах розвитку акселераційних програм на локальному рівні, залишаючи елементами загальної екосистеми інноваційного підприємництва. У результаті цього виникає потреба переусвідомлення цифровізації для реалізації всіх функцій менеджменту, вимагається пошук наукових рекомендацій щодо забезпечення цифровізації управління та розроблення дієвих інструментів забезпечення гнучкості прийняття управлінських рішень.

Аналіз останніх досліджень і публікацій. Питання управління та його ефективності розглядались у працях вітчизняних і закордонних науковців, зокрема Р. Блейка Д. Мутона [1], М. Денисенка [2], Ю. Погорєлова [3], К. Шапошникова [4] та інших. Проблема якості управлінських рішень $€$ пред-метом наукових досліджень Н. Кондратенко [5], Р. Федоряка [6], О. Щербакова [7] та інших. Сьогодні сучасні економісти-практики проводять дослідження щодо цифровізації економіки, а також ґрунтовні дослідження потенціалу зародження й ефрективного фрункціонування інноваційного підприємництва в умовах діжиталізації, зокрема стартапів - це А. Гавриш [8], Н. Краус [9], В. Орлов [10] та інші. Проте проблемі забезпечення гнучкості прийняття управлінських рішень та цифрровізації управління на інноваційних підприємствах і стартапах поки що не приділено належної уваги, тому що вона $€$ новою і недостатньо вивченою, підсиленою умовами локдауну-2020. А тому $є$ необхідність подальшого розвитку аспектів управління на інноваційних підприємствах і стартапах в умовах цифровізації економічних процесів і явищ та необхідності гучності у прийнятті управлінських рішень.

Постановка завдання. Метою статті $€$ визначення основних напрямів забезпечення цифровізації управління на інноваційних підприємствах і стартапах та забезпечення гнучкості прийняття управлінських рішень.

Виклад основного матеріалу дослідження. Цифровізація управління - процес, що має бути визначений стратегією кожної компанії, особливо коли йдеться про інновації. Процес якісних змін відбувається за посилення інтеграційного зв'язку між інноваційними підприємцями, локальним та венчурним бізнесом, наукою, освітою. Орієнтація на діджитал-орормат змінює завдання управління, трансорормує конотацію функцій і впливає на структуру. Тому цінним $€$ розвиток талантів, компетенцій, команд та організаційної культури для забезпечення як ефективності управління, так і сталого розвитку в глобальному вимірі завдяки здійсненню локальних дій.

Про питому вагу інноваційних компаній і їх внесок у розвиток світової економіки-2020 можна говорити за показниками топ-5 стартапів українського походження, що продовжують залучати інвестиції та інвесторів (табл. 1) [11].

Як можемо встановити, понад 1 млрд дол залучили стартапи у період пандемії, і $€$ бачення масштабування до рівня юнікорнів. Водночас йтиметься про ефрективний менеджмент та швидку реакцію на запит ринку за допомогою сучасних технологій.

Технологічна компонента невіддільна від зміни підходів до організації бізнес-процесів. В інноваційні бізнеси йдуть найпрогресивніші, тому наявні управлінські підходи, що уможливлюють виконання управлінських функцій, потрібно змінювати на користь забезпечення необхідної динаміки. У цьому контексті зазначимо, що навіть час на пошук і підбір працівників скорочуватиметься, а методи мотивації переглядатимуться. За умови формування стабільних колективів і сильних команд гнучкість управління ставатиме «нормою».

Таблиця 1

Топ-5 стартапів за розміром залучених інвестицій у 2020 році

\begin{tabular}{|c|c|c|c|c|}
\hline $\mathbf{N}$ & $\begin{array}{c}\text { Назва } \\
\text { стартапу }\end{array}$ & Менеджмент ідеї & $\begin{array}{c}\text { Сума інвестицій, } \\
\text { млн дол }\end{array}$ & $\begin{array}{c}\text { Інвестор, } \\
\text { акселератор }\end{array}$ \\
\hline 1 & Revolut & $\begin{array}{l}\text { Британський фрінтеч-проєкт "банк без відділень"; } \\
\text { всі операції виконуються через мобільні застосунки } \\
\text { у смартфроні (засновник Владислав Яценко) }\end{array}$ & 500 & $\begin{array}{l}\text { Technology Crossover } \\
\text { Ventures }\end{array}$ \\
\hline 2 & Astromix & $\begin{array}{l}\text { Розроблення персоналізованих гороскопів: } \\
\text { за професією, типом особистості, талантам, } \\
\text { астропрогнози, календарі (засновник Дмитро Ткаченко) }\end{array}$ & 300 & Adventures Lab \\
\hline 3 & Elision & $\begin{array}{l}\text { Платорорма підкастингу, що дає змогу авторам } \\
\text { контенту заробляти на ньому, а слухачам - } \\
\text { отримати необмежений доступ до всіх підкастів, } \\
\text { які є і інтернеті (засновник Віктор Павлучинський) } \\
\end{array}$ & 150 & Genesis Investments \\
\hline 4 & Propertymat & $\begin{array}{l}\text { Платорорма для агентів з продажу нерухомості, } \\
\text { що дає змогу об'єднати дані про покупців } \\
\text { і нерухомость на ринку (засновники } \\
\text { Богдан Гнатковський і Софія Вишневська) } \\
\end{array}$ & 120 & Techstars Austin \\
\hline 5 & Go To-U & $\begin{array}{l}\text { Платорорма для об'єднання бізнесів, які володіють } \\
\text { зарядними станціями, і власників електромобілів; } \\
\text { користувачі можуть забронювати чарджер, а також } \\
\text { спланувати маршрут і скористатись іншими бонусами }\end{array}$ & 100 & Techstars \\
\hline
\end{tabular}


Гнучкість прийняття управлінських рішень повинна буде поширюватися на питання розподілу ролей у стартап-командах, статусів і організаційної структури, розподілу робіт на інноваційних підприємствах.

Для появи стартапу потрібна ідентифрікація проблеми, «болю», що мають споживачі, що вимагає пропозицій щодо вирішення. Формуються команди, що мають ролі (СЕО, СТО ті ін.), працюють спільно, напрацьовують відповідальні рішення, - процеси гнучкості закладено в місії стартапів. Щодо інноваційних підприємств, що набагато раніше започатковували свою діяльність, аніж розвинулась екосистема інноваційного підприємництва, то прийняття рішень вимагає моніторингу і «втручання» менеджерів, необхідної та швидкої реакції на забезпечення динаміки управлінського процесу загалом завдяки реагуванню на ситуації, пов'язані з об'єктом управління, особливо за умов переведення їх з одного стану в інший, що і визначено цілями і завданнями управління.

Для досліджуваних суб'єктів більше ніж важливо, щоб управлінське рішення відповідало вимогам гнучкості і передбачало можливість його коригування у разі суттєвих змін певних умов фрункціонування, що $€$ невід'ємною складовою частиною їхньої діяльності, зокрема найбільше впливатимуть непевність, ризики, тривалість і фрази життєвого циклу; а нові управлінські моделі мають підкріплювати створення доданої вартості. Відповідальності за прийняті рішення додають умови надання фрінансування, зокрема гранти. Від держави Україна стартапи отримали 300 тис. дол., навіть в умовах дії карантинних обмежень, що вимагатиме посилення фрінансової дисципліни за загальної тенденції до лібералізації економічних відносин завдяки впроваджуваним інноваціям та забезпечення гнучкості прийняття рішень в умовах діджиталізації управління (рис. 1) [12].

Перевага інноваційних підприємств полягає у максимальному залученні команд до розроблення і впровадження ідей і рішень, в уможливленні створення умов для розуміння особистої відповідальності кожного за результат. Тому мотиваційна фрункція управління на кожній фразі життєвого циклу стартапу реалізовуватиметься за допомогою різних технологій, методів, інструментів. Системи оплати праці на ранніх і пізніх етапах будуть кардинально різними:

1) на ранніх - залучення, нематеріальні методи, трудова мотивація;

2) на пізніх - матеріальна, статусна мотивація, яку в умовах стартапів пропонуємо визначати як «рольову», тому що саме в стартапах ролі визначаються на preseed-стадії та реалізуються протягом життєвого циклу продукту стартапу, трансорормуючись за потребою в періоди seed, акселерації, масштабування.

Мотиваційна фрункція не потребуватиме «плану підвищення кваліфікації», тому що час навчання буде імплементовано в діяльність самим персоналом, спрощуючи процедури планування інноваційних проєктів за допомогою діджитал-інструментів та сучасного програмного забезпечення. Надалі популяризуватиметься онлайн-формат навчання, поступово витісняючи оффрлайн, розвиток навичок і компетенцій з мінімальними інтервенціями в особистий час учасників стартап-команд, супроводжуючи віддалену роботу і гнучкі форми зайнятості. Завдяки рольовій структурі та розвитку комунікацій в командах нівелюватиметься архаїчна проблема «ставлення керівництва до підлеглих» цифровізація управління мінімізує суб'єктивізм і особистісні реолексії на колективи і команди.

щодо такої функції менеджменту, як планування, то відкритість даних компаній інноваційного типу та пізнаваність створюваних брендів через використання відкритих платорорм, створення плагінів і датасетів дає змогу усунути ще одну проблему, притаманну українським компаніям, - проблему закритості інфрормації, планів, перспектив розвитку для співробітників та витрат на виготовлення паперової продукції і нераціональності структури гро-шових потоків, до того ж наносячи цим шкоду довкіллю. Перевагою планування за цифрровізації управління $€$, зокрема, планування завдань, таймінгу на виконання ітерацій, рольової та соціальної структури працівників, якості персоналу, інклюзивності операцій у компанії, визначення функцій, що можуть бути віддані на аутсорсинг.

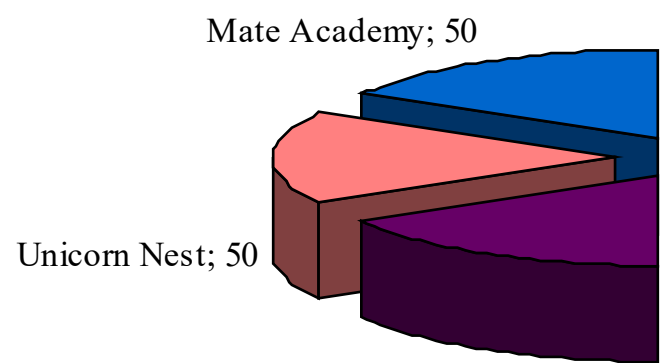

Cardiolyse; 50

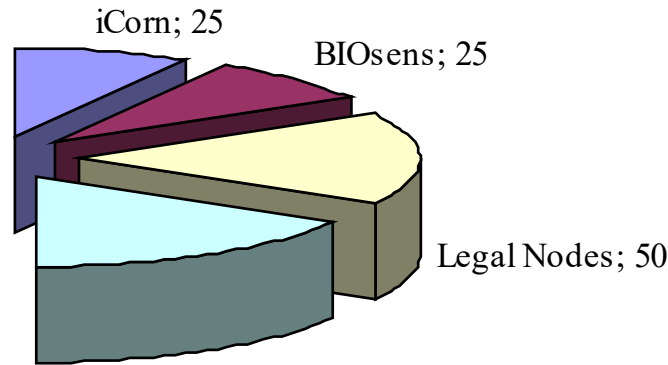

ChoiZY; 50

Рис. 1. Розмір грантів від держави українським стартапам у 2020 році, тис. дол. 
Організація з використанням діджитал-платформ дає змогу пришвидшити процеси навіть в аспекті забезпечення оптимальної структури й тими особистісними та професійними компетенціями, що задовольняють вимоги робіт і забезпечують конкурентоспроможність інноваційного підприємства. Це сприяє зменшенню навантаження на фронд оплати праці через скорочення середньооблікової чисельності штатних працівників та передачу частини робіт підрядним організаціям. Навіть на підприємствах інформаційно-комунікаційної сорери країни завдяки впровадженню цифровізації управління у структурі персоналу почала переважати не «потребова», а «результативна» структура інноваційних департаментів, зокрема оптимізовано на користь результату завдяки правильно організованій роботі чисельність менеджерів із роботи 3 клієнтами, інженерів із телекомунікацій, інженерів з експлуатації телефонної мережі з комутацією каналів та інженерів зв'язку.

Як наслідок, координація в зазначеному вище сегменті дає змогу вже стверджувати про досить високий рівень освіченості працівників та ефективність реакції на зміни зовнішнього і внутрішнього середовищ. Під час формування колективів і команд поєднується досвід практичної роботи молодого і більш досвідченого персоналу у вибраній сорері діяльності.

Контроль дає змогу уможливити отримання результату незалежно від підходу (і за результатами діяльності, і за якістю, і за рівнем дисципліни), але в умовах цифровізації управління виконання цієї фрункції стало максимально комфортним і таким, що не вимагає надзусиль СEO, CTO, CFO чи функціональних менеджерів.

За результатами проведеного нами опитування серед підприємств інноваційного типу, тих, які впроваджують інновації, стартапів, отримано відповідь, що відсоток цифровізації управління в компаніях становить близько 30\%, а в стартапах - 50\%. Прогнозуємо, що ця цифра збільшуватиметься і за збереження поточних темпів цифровізації економіки й розвитку інноваційних бізнесів до 2030 року зросте на 8-15\%.

Висновки 3 проведеного дослідження. За результатами проведеного дослідження можемо стверджувати, що сучасними інструментами для забезпечення гнучкості прийняття управлінських рішень є: онлайн-платформи та системи відеозв'язку; гнучкі форми організації праці та можливість колективам і командам комунікувати і працювати разом із відкритими даними; програмне забезпечення 3 можливістю завантаження плагінів і датасетів; ефективний менеджмент ролей.

Основними напрямами удосконалення управління на інноваційних підприємствах і стартапах
$€$ подальша діджиталізація виконання управлінських фрункцій, пріоритезація цілей і завдань, визначення «точок росту» і перспектив масштабування бізнесу командами, можливості коригування рішень у разі суттєвої зміни певних умов фрункціонування.

\section{БІБЛІОГРАФІЧНИЙ СПИСОК:}

1. Р.Р. Блэйк, Д.С. Мутон. Научные методы управления. Київ : Вышейшая школа, 2013. 274 с.

2. Денисенко М.П. Стан та тенденції розвитку сучасного підприємництва : монографрія. Київ : ТОВ «ДКС центр», 2019. 464 с.

3. Погорєлов Ю.С. Вибір способів розвитку підприємства. Вісник Хмельницького національного університету. 2015. № 4. Т. 2. С. 79-85.

4. Шапошников К.С. Вплив інституційного середовища на інноваційний розвиток економіки регіону. Причорноморські економічні студії. 2018. Вип. 29(2). С. 34-36.

5. Кондратенко Н.О., Новікова М.М., Гнатенко М.К. Поліпшення якості прийняття управлінських рішень в організації. Збірник наукових праць ЧДТУ. 2018. Вип. 51. С. 55-62.

6. Федоряк Р.М., Худік О.О. Обґрунтування управлінських рішень в системі менеджменту підприємства. Технології та дизайн. 2014. № 3(12). URL: http://nbuv.gov.ua/UJRN/td_2014_3_15 (дата звернення: 26.11.2020).

7. Щербаков О., Наришкін В. Система підтримки прийняття рішень як невід'ємна частина сучасного інорормаційного забезпечення для управління бізнесом. Інорормаційні технології в технологічних системах. 2011. № 3. С. 93-96.

8. Гавриш О.А., Бояринова К.О., Копішинська К.О. Розробка стартап-проектів: Конспект лекцій : навч. посіб. для студ. спеціальностей 151 - «Автоматизація та комп'ютерно-інтегровані технології» та 152 - «Метрологія та інфрормаційно-вимірювальна техніка». КП। ім. Ігоря Сікорського. Електронні текстові дані (1 фрайл: X,XX Мбайт). Київ : КПІ ім. Ігоря Сікорського, 2019. 188 с.

9. Краус Н.М., Голобородько О.П., Краус К.М. Цифрова економіка: тренди та перспективи авангардного характеру розвитку. Еорективна економіка : елект-рон. наук. фрахове вид. 2018. № 1. URL:http://ojs.dsau.dp.ua/index.php/efektyvnaekonomika/ article/view/ 997/862. (дата звернення: 26.11.2020).

10. Орлов В.М., Князєва О.А., Князєв О.А. Визначення ефрективності впрова-дження інноваційних проектів. Глобальні та національні проблеми еконо-міки. 2015. № 3. C. 370-375. URL: http://global-national.in.ua/ vipusk-3-2015/395-orlov-v-m-knyazeva-o-a-knyazevo-a-viznachennya-efektivnosti-vprovadzhennyainnovatsijnikh-proektiv (дата звернення: 26.11.2020).

11.Инвестиции в украинские стартапы за полгода 2020-го - список. URL: https://ain.ua/2020/07/20/vseinvesticii-2020 (дата звернення: 27.11.2020).

12. 7 украинских стартапов получили гранты от государства. От \$25000 до \$50 000 каждый. URL: https://ain.ua/2020/06/11/usf-razdal-granty-7-startapam (дата звернення: 27.11.2020). 


\section{REFERENCES:}

1. Blake R., Mouton J. (2013) Nauchnye metody upravleniya [Scientific methods of management]. Kyiv: Vysheyshaya shhkola. (in Russian)

2. Denysenko M. (2019) Stan i tendencii rozvytku suchasnogo pidpryemnytstva [State and tendencies of modern entreneurship development]. Kyiv: DKS Center. (in Ukrainian)

3. Pogorielov lu. (2015) Vybir sposobiv rozvytku pidpryemstva [Choosing the ways for enterprise's development]. Visnyk Khmelnitskogo natsionalnogo universiteta, vol. 4, t. 2, pp. 79-85.

4. Shaposnikov K. (2018) Vplyv instytutsijnogo seredovyscha na innovatsijnij rozvytok ekonomiki regionu [The influence of the institution environment on regional economy development]. Prychornomorski ekonomichni studii, vol. 29(2), pp. 34-36.

5. Kondratenko O., Novikova M., Gnatenko M. (2018) Polipshennia iakosti pryjniattia upravlinskih rishen' $v$ organizacii [Increasing the quality of decision-making processes in the organisation]. Zbirnyk naukovyh prats' ChDTU, vol. 51, pp. 55-62.

6. Fedoryak P., Chudik O. (2014) Obguntuvannya upravlinskih rishen' $v$ systemi menedzhmentu pidpryemstva [Verification of management decisions in management system of enterprise]. Technologii I dizajn, vol. 3(12). Available at: http://nbuv.gov.ua/UJRN/td 2014_3_15 (accessed 26 November 2020).

7. Scherbakov O., Naryshkin V. (2011) Systema pidtrymki pryinyattya rishen' jak nevid'emna chastyna suchasnogo informatsijnogo zabezpechennia dlia upravlinnia biznesom [Support system to decision making as the one of the main parts of informational basic for managing business]. Informatsijni technologii $v$ informatsijnyh systemah, vol. 3, pp. 93-96.

8. Gavrish O., Boiarinova K., Kopishynska K. (2019) Startup projects development. Kyiv: NTTU KPI named after Ihor Sikorski.

9. Kraus N., Goloborod'ko O., Kraus K. (2018) Tsifrova ekonomika: trendy i perspektivy avangardnogo kharaktera rozvytku [Digital economy: trends and prospectives of the priority character of development], vol. 1. URL: http://ojs.dsau.dp.ua/index.php/efektyvnaekonomika/article/view/997/862 (accessed 26 November 2020).

10. Orlov V., Knyazeva O., Knyazev O. (2015) Vyznachennya efectyvnosti vprovadzhennia innovatsijnyh proektiv [Determining the effectiveness of implementation of innovative projects]. Global'ni ta natsional'ni problemy ekonomiki, vol. 3, pp. 370-375. UR: http://global-national.in.ua/vipusk-3-2015/395-orlov-v-m-knyazeva-o-a-knyazev-o-a-viznachennya-efektivnosti-vprovadzhennya-innovatsijnikh-proektiv (accessed 26 November 2020).

11. AIN.UA (2020) Investicij v ukrainskie startupy za polgoga 2020-go [Investments in Ukrainian startups]. Available at: https://ain.ua/2020/07/20/vse-investicii2020 (accessed 27 November 2020).

12. AIN.UA (2020) 7 ukrainskih startapov poluchili granty ot gosudarstva. Ot $\$ 25000$ do $\$ 50000$ - kazhdomu [7 Ukrainian startups recieved grants from the state. From $\$ 25000$ to $\$ 50000$ to each]. Available at: https://ain.ua/2020/06/11/usf-razdal-granty-7-startapam (accessed 27 November 2020). 